Special Article

\title{
Human Nonspecific Suppressive Lymphokines
}

\author{
MICHAEL T. HALPERN ${ }^{1}$
}

\begin{abstract}
Accepted: September 27, 1990
Since the term "lymphokine" first appeared in print over 20 years ago, a tremendous number of these soluble mediators of the immune system have been described. Within the past few years, many human nonspecific suppressive lymphokines have been identified. This review discusses the historical basis of immunologic suppression and suppressor factors. Later reports describing suppressive human lymphokines are then grouped into four categories: primarily stimulatory lymphokines that also mediate certain suppressive activities, suppressive lymphokines produced during altered states of immunity, suppressive lymphokines produced by exogenously stimulated lymphocytes, and suppressive lymphokines produced by unstimulated lymphocytes. Recent work I have been involved in focusing on the human suppressive lymphokine soluble suppressor factor (SSF) is also discussed.
\end{abstract}

KEY WORDS: Immunosuppression; lymphokines; suppressive factors; review.

\section{INTRODUCTION}

Over the past few years, there has been a tremendous increase in the number of identified human lymphokines. A majority of these lymphokines have been stimulatory or helper factors. However, a large number of suppressive lymphokines have also recently been described. This review examines the historical basis of immunologic suppression and suppressor factors and then discusses a number of different types of suppressive lymphokines. The

\footnotetext{
${ }^{1}$ Graduate Program in Cellular and Molecular Biology and Department of Epidemiology, University of Michigan, Ann Arbor, Michigan 48109.
}

review concludes by discussing recent work with the lymphokine soluble suppressor factor (SSF).

\section{HISTORICAL BACKGROUND OF IMMUNOLOGIC SUPPRESSION}

The term "lymphokines" was first used by Dumonde et al. approximately 20 years ago (1). Lymphokines were defined as "cell-free soluble factors, which are generated during interaction of sensitized lymphocytes with specific antigens." Lymphokines were further differentiated from antibodies as being "expressed without reference to immunological specificity." Dumonde et al. demonstrated four functions of lymphocyte-produced soluble factors in a guinea pig model: induction of intradermal inflammation, transformation of lymphocytes, cytopathic action on fibroblast monolayers in culture, and inhibition of migration of peritoneal macrophages.

The cellular basis of suppression of the immune system was also first demonstrated approximately 20 years ago, by Gershon and Kondo (2). In these classic experiments, adult mice were made tolerant to sheep red blood cells (SRBC). Cells from these tolerant mice could be transferred to naive mice (mice not previously exposed to SRBC), and these recipient mice would then also be tolerant to SRBC. This induction of tolerance was shown to be mediated by the transfer of a Lyt $2,3^{+}$T-cell subset, later known as $\mathrm{T}$-suppressor cells $\left(\mathrm{T}_{\mathrm{s}}\right)$. Gershon et al. later showed that $T_{s}$ cells are capable of suppressing immunologic responses by other $\mathrm{T}$ cells without the aid of B cells or antibodies (3). 
Merging of the concepts of lymphokines and immunologic suppression was first seen in studies by various investigators including Tada, Benacerraf, and others on antigen-specific suppressive lymphokines. $T_{s}$ cells were collected from mice that did not respond to or had been made tolerant to a specific antigen, such as keyhole limpet hemocyanin $(\mathrm{KLH})$ or L-glutamine-L-alanine-L-tyrosine (GAT). Cell-free extracts from these $T_{s}$ cells were prepared by sonication, and these extracts were injected into mice that would normally respond to the specific antigen. These recipient mice then showed decreased immune responses to the specific antigen (4).

These suppressive factors, called $T_{s} F$, are thought to be products of $T_{s}$-cell subsets stimulated by their specific antigen. All share a number of biochemical properties, including being proteins with molecular weights between 35 and $60 \mathrm{kD}$, specifically binding the antigen used to stimulate $T_{s}$ cells to make this factor, and bearing determinants coded by a component of the mouse MHC class II region ( $\mathrm{H}-2)$ called the $\mathrm{I}-\mathrm{J}$ region, and acting only in mice strains syngeneic to the strain which produced the factor $(4,5)$. It has also been reported that the target of $\mathrm{T}_{\mathrm{s}} \mathrm{F}$ is the Lyt $1,2,3^{+} \mathrm{I}-\mathrm{J}^{+} \mathrm{T}$-cell subset. $T_{s} F$ causes the latter cells to become active $T_{s}$ cells (4-6).

Later research has indicated that there are at least two and possibly three or more levels of antigen-specific $T_{s}$ cells and $T_{s}$-cell factors operating in a complex network of regulation. Initially, it was proposed that antigen stimulated a cyclophosphamide-sensitive class of $T_{s}$ cells designated $T_{s 1}$ $(5,6)$. These cells produce a factor, $T_{s} F_{1}$. This factor is a single-chain polypeptide containing an antigen-binding site and MHC-encoded determinants and is not genetically restricted to syngeneic strains. $T_{s} F_{1}$ activates a second class of $T$-suppressor cells, the cyclophosphamide-resistant $T_{\mathrm{s} 2}$ cells. $\mathrm{T}_{\mathrm{s} 2}$ cells then produce a second factor, $\mathrm{T}_{\mathrm{s}} \mathrm{F}_{2}$, which consists of two-polypeptide chains linked by a disulfide bond. One of the chains bears an MHCencoded determinant; the other appears to contain either an antigen-binding site or an idiotype-specific site. This factor is genetically restricted to function only in syngeneic mice. $T_{s} F_{2}$ may then stimulate one of more other sets of T-suppressor cells $\left(T_{\mathrm{s} 3}\right)$ resulting in suppression of specific effector functions $(5,6)$. For example, $\mathrm{T}_{\mathrm{s}} \mathrm{F}_{2}$ may stimulate the so-called auxiliary cells which function to suppress contact sensitivity. These cells could then produce a third suppressor factor $\left(\mathrm{T}_{\mathrm{s}} \mathrm{F}_{3}\right)$, which would actually mediate immunologic suppression (7).

These various putative T-suppressor factors have yet to be isolated or purified. However, their existence has been called into doubt by difficulties in locating the I-J locus in the murine MHC. Numerous reports have indicated that at least some of these factors interact with antisera to determinants coded for by the $\mathrm{K}$ end of the mouse $\mathrm{H}-2$ region (8). These determinants, as discussed above, were designated I-J. Reports map the I-J locus "unambiguously" to the mouse MHC (9). However, molecular mapping of the mouse $\mathrm{MHC}$ indicates that the two regions surrounding the $\mathrm{I}-\mathrm{J}$ region (the $\mathrm{I}-\mathrm{A}$ and I-E regions) are separated by no more than $3.4 \mathrm{~kb}$ and may be separated by less than $1 \mathrm{~kb}$ or may even be continuous (10). Thus, it is difficult to envision at least one and possibly two (I-J and I-B) polymorphic regions within such a short span of DNA. If the I-J region does exist, other possible locations include existing outside of the murine I region; having identity with $E_{\text {beta }}$ or a fragment of $E_{\text {beta }}$ but differing in posttranslational modification and/or conformation; and being produced from differential RNA splicing of a polymorphic RNA encoded by I-A, I-E, or a region between I-A and I-E (10).

\section{SUPPRESSIVE ACTIVITIES OF PREDOMINANTLY STIMULATORY LYMPHOKINES}

While a large body of literature exists on antigenspecific suppressive lymphokines in mice, few studies have been performed in humans on this type of factor $(11,12)$. Most corresponding studies in humans have identified nonspecific suppressive lymphokines. A number of reviews on this topic have been published (13-16). Nonspecific suppressive lymphokines fall into two broad classes: predominantly stimulatory lymphokines which also have suppressive functions and lymphokines which appear to be only suppressive. Interferon (IFN) gamma falls into this first class. IFN-gamma is a product of stimulated $\mathrm{T}$ and $\mathrm{B}$ cells. In humans, IFN-gamma has been shown to inhibit: lymphocyte proliferation to certain mitogens, antigens, and allogeneic cells $(17,18)$; certain B-cell functions $(19)$; and the mixed lymphocyte reaction (MLR) (17). Recombinant IFN-gamma has also been reported to induce a brief enhancement of IL-2-stimulated lymphokine-activated killer (LAK) cells after 2 days of in vitro incubation followed by a pronounced inhibition of LAK activity after 6 days (20). IFN- 
associated suppression may occur with IFN concentrations as low as $10 \mathrm{U} / \mathrm{ml}(17)$. Johnson and Blalock (21) have shown that IFN can activate suppressor cells in mice that produce a soluble factor capable of suppressing plaque-forming cell (PFC) responses to SRBC. This suppressor factor may be similar or identical to a well-known suppressor factor, the soluble immune response suppressor (SIRS) (discussed below).

Another predominantly stimulatory factor with suppressive actions is the family of transforming growth factors (TGF). These peptides can induce nonneoplastic cells to express transformed phenotypes. The most thoroughly characterized factor of this family is TGF-beta. TGF-beta is a $25-\mathrm{kD}$ homodimer produced by a number of cell types and capable of suppressing B- and T-cell proliferation and NK-cell cytotoxicity (22). Other suppressive effects of TGF-beta include inhibition of IL-1induced lymphocyte proliferation. This suppression is not due to a direct $\mathrm{IL}-1$ inhibitor, as discussed below, as the suppression occurs distal to the IL-1 receptor (23).

The mechanism of TGF-beta-mediated suppression is uncertain. TGF-beta does not suppress augmentation of NK cytotoxicity by exogenous IL-2 but does suppress augmentation by exogenous IFN. This suggests that TGF-beta functions by inhibiting enhancement of NK cytotoxicity by endogenous IFN (22). However, TGF-beta can suppress IL-2driven LAK-cell proliferation and cytotoxicity in a dose-dependent manner at concentrations as low as $5 \mathrm{ng} / \mathrm{ml}(24)$. It has also been proported that TGFbeta may exert suppressive activities by downregulation of lymphocyte cell surface receptors (22).

Other predominantly stimulatory factors that also have limited suppressive abilities include IL-6, which inhibits the growth of certain myeloid leukemic cells lines and breast carcinoma cell lines (25); IL-4, which inhibits IL-2 and lipopolysaccharide (LPS)-mediated stimulation of the production of certain immunoglobulins $(26,27)$; and connective tissue activating peptide I (CTAP-I), which can indirectly mediate immunosuppression by stimulating production of prostaglandin $\mathrm{E}_{2}(28)$.

\section{SUPPRESSIVE LYMPHOKINES PRODUCED IN STATES OF ALTERED IMMUNITY}

A number of lymphokines have been described as being produced primarily or solely in disease states or other states characterized by altered immune responses. Linker-Israeli and Casteel (29) have described factors produced by unstimulated peripheral blood mononuclear cells (PBMC) from patients with systemic lupus erythematosus (SLE). These factors, termed SF PBM, suppressed production of IL-2 by PHA-stimulated PBMC from healthy subjects or SLE patients and IL-2 production by Jurkat cells, a constitutive IL-2-producing cell line. Both monocytes and $\mathrm{CD}^{+}$lymphocytes were necessary to produce this suppressive activity. SF PBM did not inhibit proliferation of IL-2-dependent or -independent cell lines and had no IFN activity. These factors are sensitive to acid $(\mathrm{pH} 2), 56^{\circ} \mathrm{C}$, and trypsin. Two molecular weight ranges of SF PBM activity were detected by gel filtration, $\angle 150 \mathrm{kD}$ (fraction II) and 40 to $60 \mathrm{kD}$ (fraction IV). Fraction II mediated suppression in a manner similar to unseparated SF PBM, while fraction IV was active only when monocytes were present. This suggests that fraction IV requires monocyte processing for activity such as the suppressive lymphokine SIRS, discussed below; however, 2-mercaptoethanol, an inhibitor of SIRS activity, had no effect on either fraction.

Pregnancy, while clearly not a disease state, is characterized by alterations in immunity. Nagaoki et al. (30) have shown that pokeweed mitogen (PWM)-stimulated cord blood $\mathrm{T}$ cells produce a dialyzable factor capable of suppressing the generation of plasma cells by PWM stimulated adult peripheral blood lymphocytes (PBL). Cord non-T cells, adult $T$ cells, or adult non- $T$ cells were incapable of producing this suppressive factor. Development of suppressive activity took at least $12 \mathrm{hr}$ following PWM stimulation and was no longer produced after $48 \mathrm{hr}$ poststimulation. This factor, named cord $\mathrm{T}$ cell-derived suppressive factor (CTSF), is stable at $56^{\circ} \mathrm{C}$ for $30 \mathrm{~min}$ but is inactivated at by treatment at $80^{\circ} \mathrm{C}$ for $10 \mathrm{~min}$ (31). Production of CTSF activity was abrogated by irradiating cord $T$ cells with 1000 rads (30).

Williams and Korsmeyer (32) have studied suppression mediated by supernates from Con A-activated lymphocytes in two other immunologically altered states. Supernates from a subset of healthy individuals were capable of suppressing the MLR. A greater proportion of supernates from cord blood samples or from subjects with common variable immunodeficiency showed suppression of the MLR. This suppressive activity was stable at $56^{\circ} \mathrm{C}$ but inactivated at $70^{\circ} \mathrm{C}$. Suppressive activity was 
disrupted by treatment at $\mathrm{pH} 2.0$ or with chymotrypsin but was resistant to neuraminidase, RNase, or DNase. This activity may be identical to other suppressive factors discussed herein, but definitive purification and characterization have not been reported.

Several investigators have examined suppressive lymphokines produced in human immunodeficiency virus (HIV)-infected individuals. Laurence et al. (33) have shown that supernates from cultured PBMC of patients with the acquired immune deficiency syndrome (AIDS) or its prodrome were capable of suppressing spontaneous and PWMstimulated differentiation of $B$ cells as well as antigen-mediated T-cell transformation, while no such suppressive activity was found in comparable supernates of healthy controls. These supernates did not affect $\mathrm{T}$ cell-independent immune responses. Suppressive activity was produced by the interaction of $T$ cells with adherent cells. $T$ cells from AIDS patients, but not from healthy controls, in collaboration with adherent cells from healthy control individuals were also capable of producing this activity. This activity was reversed by 2 -mercaptoethanol, suggesting that the activity may be similar to the soluble immune response suppressor (SIRS), discussed below.

Henderson et al. (34) have examined a suppressive factor(s) produced by healthy individuals in response to ultraviolet-irradiated HIV (uv-HIV). Cultures of healthy PBMC exposed to uv-HIV in the presence of PHA produce supernates capable of suppressing PHA-induced proliferation in other PBMC cultures. Supernates from PBMC cultures either untreated or treated with only PHA did not mediate this suppression. Suppression was not due to the presence of the uv-irradiated HIV or residual HIV proteins. This suppressive activity is sensitive to heat $\left(1 \mathrm{hr}\right.$ at $\left.56^{\circ} \mathrm{C}\right)$ and trypsin. It was suggested that this immunosuppression may be due to killing of $\mathrm{CD} 4^{+}$cells.

\section{SUPPRESSIVE LYMPHOKINES PRODUCED BY EXOGENOUSLY-STIMULATED LYMPHOCYTES}

A number of factors have been described that are produced by concanavalin $\mathrm{A}$ (Con $\mathrm{A}$ )- or pokeweed mitogen (PWM)-activated lymphocytes or lymphocyte subsets. One of the first sets of Con A-activated factors to be characterized is the family of migration inhibitory factors: fibroblast migration inhibiting factor (FIF), leukocyte migration inhibit- ing factor (LIF), and macrophage migration inhibiting factor (MIF). These factors are all similar in function, inhibiting migration of their target cells specifically without inhibiting other functions of these cells.

MIF has both stimulator and inhibitor activities, as MIF-mediated inhibition of monocyte/macrophage migration mediated by MIF is also correlated with cutaneous delayed-type hypersensitivity (DTH). MIF is actually a group of peptides, ranging in molecular weight from 23 to $65 \mathrm{kD}$ and in $\mathrm{pI}$ from 2.4 to 5.6. These differences are not due to alterations in glycosylation, as tunicamycin does not convert one species into another (35). Characteristics of MIF include stability at $56^{\circ} \mathrm{C}$; inhibition by L-fucose, L-rhamnose, and other 5-methylpentoses; and binding to a cell surface glycolipid receptor containing both fucose and sialic acid $(35,36)$. MIF can apparently be produced by either T or B cells alone, without the influence of the other subset of lymphocytes (37). Abnormalities in the production of MIF may play a role in disease symptomology, as lymphocytes from subjects with DiGeorge's syndrome do not produce MIF (38). This also suggests that at least small numbers of $T$ cells must be present with B cells for MIF production.

LIF has an approximately molecular weight of 69 $\mathrm{kD}$ and is produced by $\mathrm{T}$ and $\mathrm{B}$ cells following antigen or mitogen stimulation. LIF, similar to MIF, has both suppressive and stimulatory activities, as LIF-mediated lymphocyte migration inhibition occurs in concert with cellular hypersensitivity (37). LIF activity is inhibited by $N$-acetyl-Dglucosamine (39). LIF appears to function as both an esterase and a protease as demonstrated by its susceptibility to phenylmethylsulfonyl fluoride (PMSF), an irreversible enzyme inhibitor (40). Treatment of PMN with LIF elevates intracellular cGMP levels (41), while the production of LIF is inhibited by agents which increase intracellular cAMP (42).

FIF is an approximately $34-\mathrm{kD}$ molecular weight factor that, as the name suggests, specifically inhibits the migration of fibroblasts. FIF activity is disrupted by incubation at $80^{\circ} \mathrm{C}$, and treatment with trypsin, chymotrypsin, and neuramididase, and is blocked by L-xylose, $N$-acetyl-D-glucosamine, D-mannose, L-rhamnose, and alpha-methyl-Dmannoside but not by L-fucose (39). A T-cell migration inhibitory factor (TIF) has also been described (43). This factor is produced by cultures of PHAtreated $T$ cells and inhibits migration of human $T$ 
lymphocytes. TIF activity has a molecular weight of 1 to $10 \mathrm{kD}$, an isoelectric point of 3.1 , and can be separated from MIF by polyacrylamide gel electrophoresis. TIF activity is resistant to trypsin, chymotrypsin, and neruaminidase but, like LIF, is inhibited by PMSF.

Soluble immune suppressor supernates (SISS) consists of two factors also produced by Con A-stimulated lymphocytes: SISS-T and SISS-B (36). SISS-T inhibits mitogen- and antigenstimulated T-cell proliferation. Characteristics of SISS-T include a molecular weight of 30 to $45 \mathrm{kD}$; partial inactivation at $56^{\circ} \mathrm{C}$, complete inactivation at $80^{\circ} \mathrm{C}$; being unaffected by exposure to acid or base; partial inhibition by $N$-acetyl-D-glucosamine (NAG); production by lymphocytes resistant to $2000 \mathrm{R}$ but not to $6000 \mathrm{R}$; and binding to the same cell surface receptors as the lectin wheat germ agglutinin (WGA) and Agaricus bisporus lectin (36). The latter finding is especially interesting, as WGA has been shown to bind to IL-2 receptors and interfere with maintaining high-affinity IL-2 binding sites on activated $T$ cells, resulting in decreased peripheral blood mononuclear-cell (PBMC) proliferation (44).

SISS-B has been clearly shown to differ from SISS-T. Functionally, SISS-B inhibits in vitro immunoglobulin (Ig) production by activated B cells. SISS-B has an apparent molecular weight of 60 to $80 \mathrm{kD}$ and is stable at $\mathrm{pH} 2.5$ but is inactivated at $56^{\circ} \mathrm{C}$. The activity of SISS-B is inhibited by L-rhamnose but not affected by NAG. SISS-B is produced by highly purified $T$ cells (45). CTCSISS-B, a suppressive factor produced by an IL-2dependent suppressor T-cell line, appears to be similar or identical to SISS-B (46). CTC-SISS-B has been shown to suppress Ig production by directly interacting with activated B-cells, rather than via an indirect interaction with $\mathrm{T}$ cells or monocytes.

Another suppressor factor produced by Con A-activated lymphocytes is the soluble immune suppressor factor (SISF) (47). SISF also binds to cells at the same surface receptor(s) recognized by WGA. A recent report states that patients with a variety of cancers show increased numbers of peripheral blood lymphocyte (PBL) expressing surface receptors for WGA. These unique lymphocytes decrease in number in patients who undergo curative resection of tumors or who respond to immunotherapy but not in patients who receive noncurative resection or who do not respond to immunotherapy, suggesting that SISF may play a role in the immunosuppression evidenced in many cancers (47). As SISF has not been well characterized, it may be identical to other lymphokines such as SISS-T, which also binds to the cell surface WGA receptor.

Inhibitor of DNA synthesis (IDS) is another inhibitory lymphokine produced by Con A-stimulated lymphocytes. As the name suggests, IDS inhibits DNA synthesis by human peripheral blood lymphocytes. IDS suppresses lymphocyte proliferation in response to antigens and lectins (48). Human IDS has a $\mathrm{p} I$ of 3.4 and a molecular weight of $20 \mathrm{kD}$; however, IDS is usually found in an $80-\mathrm{kD}$ tetrameric form. IDS' activity is inhibited by trypsin but is resistant to heat, RNAse, and DNAse. Periodate treatment also inhibits IDS-mediated suppression, suggesting that IDS is a glycoprotein and the carbohydrate moiety is necessary for suppressive functions (49). The mechanism of IDSmediated suppression appears to be activation of adenylate cyclase activity in target cells (50). Suppression mediated by IDS is specific for DNA synthesis. IDS inhibits DNA synthesis in PHAstimulated PBMC but has negligible effects on protein and RNA synthesis in these cells, including production of IL-2, IL-2 receptor, and transferrin receptor. This further suggests that the mechanism of action of IDS is IL-2 independent (48).

Pancre et al. $(51,52)$ have described a platelet activity-suppressive lymphokine (PASL) produced by Con $\mathrm{A}$ or antigenic stimulation of normal human $\mathrm{CD} 8^{+}$lymphocytes. PASL is capable of suppressing IgE-dependent platelet cytotoxicity against Schistosoma mansoni larvae and production of oxygen metabolites by IgE-coated platelets. PASL is also produced by T lymphocytes from $S$. mansoniinfected humans when stimulated by $S$. mansoni antigens. This factor has a molecular weight of 15 to $20 \mathrm{kD}$ and a $\mathrm{p} I$ of 4.6. PASL is heat and acid stable and sensitive to trypsin and proteinase $\mathrm{K}$ but is not affected by neuraminidase treatment. Indomethacin does not affect PASL production. PASL appears to act directly on platelets, suggesting that it interacts with a platelet membrane surface receptor. PASL produced by humans is capable of inhibiting rat platelet cytotoxicity and rat PASL can suppress corresponding functions of humans.

PWM-stimulated $\mathrm{CD} 4^{+}$cells have been reported to produce $\mathrm{T}$-suppressor growth factor $\left(\mathrm{T}_{\mathrm{s}} \mathrm{GF}\right)(53)$. This approximately $8-\mathrm{kD}$ factor is necessary for the proliferation and differentiation of $\mathrm{CD}^{+}$lymphocytes and functions by inducing IL-2 receptor 
expression on $\mathrm{CD} 8^{+}$cells. $\mathrm{CD} 8^{+}$cells stimulated by IL-2 plus $\mathrm{T}_{\mathrm{s}} \mathrm{GF}$ demonstrate either the $\mathrm{CD} 11^{+}$(suppressor effector) or the CD45R $\mathrm{R}^{+}$(suppressor inducer) phenotypes and are $\mathrm{CD}^{-} 8^{-}$(cytotoxic $\mathrm{T}$ cell, $\mathrm{T}_{\mathrm{c}}$, phenotype). Prostaglandin $\mathrm{E}_{2}\left(\mathrm{PGE}_{2}\right)$ and IFNgamma may also be necessary for differentiation of certain $\mathrm{CD}^{+}{ }^{+}$subsets.

Another suppressive factor produced by stimulated human lymphocytes is T cell-specific suppressive activity (TSRA), a factor produced by $\mathrm{T}$ lymphocytes stimulated by a soluble suppressor activating factor (SAF) (54). SAF is produced by a 6-thioguanine-resistant mutant of the human T-cell line, CEM. TSRA is capable of suppressing mitogen-activated $\mathrm{T}$-cell proliferation, $\mathrm{T}_{\mathrm{c}}$ generation, and PWM-stimulated PFC responses. SAF shows similar functional activities to TRSA but TRSA is 50- to 500-fold more potent. Some evidence exists that TSRA is an activated form of SAF, paralleling the SIRS system (discussed below). Release of TSRA by SAF-stimulated lymphocytes appears to be partially inhibited in rheumatoid arthritis patients (54).

Soluble inhibitory factor (SIF) is a unique factor produced by $T$ cells stimulated by tetanus toxoid or by MLR with cells from unrelated donors $(55,56)$. SIF appears to be produced by dividing $T$ cells in proportion to their rate of division. SIF mediates inhibition of DNA synthesis and proliferation of PHA-stimulated PBL as measured by decreased ${ }^{3} \mathrm{H}$-thymidine uptake, as well as inhibition of $\mathrm{Ab}$ production and PFC responses $(55,56)$ and inhibition of ${ }^{3} \mathrm{H}$-thymidine uptake in the MLR (57). Characterization of SIF has revealed that this factor has two components, a carrier protein and a polar lipid. Immunosuppression is mediated by the lipid moiety, which is termed lipid suppressor substance (LSS). LSS and the protein are apparently bound by hydrophobic interactions, and are separated by dialysis against hypotonic solutions. LSS activity is stable at $56^{\circ} \mathrm{C}$ for $30 \mathrm{~min}$ but is destroyed by $70^{\circ} \mathrm{C}$ for $15 \mathrm{~min}$. LSS is a polar lipid, possibly a glycolipid containing an amine group. However, LSS does not appear to be identical to common gangliosides (56). The protein moiety, which does not mediate mediate immunosuppression, has a molecular weight between 100 and $150 \mathrm{kD}(57)$.

Intact SIF activates a suppressor-cell population capable of inhibiting antigen- and mitogen-induced thymidine incorporation. These suppressor cells are not affected by the DNA synthesis inhibitor, mitomycin $\mathrm{C}$, indicating that their suppressor function does not require DNA synthesis. LSS by itself, however, does not appear to be capable of suppressor-cell induction. LSS may function by altering lymphocyte membrane function or fluidity (57).

SIF has also been identified in normal human sera and found to be present at very high concentrations in serum from a patient with an unusual cutaneous lymphoma (57). SIF is also produced by cultures of multinucleated giant cells obtained from the villous surfaces of normal human placentae (58).

One of the most extensively described suuppressor factors produced by stimulated lymphocytes is the soluble immune response suppressor (SIRS). Information on SIRS, both published and unpublished, has recently been reviewed by Aune (59). Much of the work on SIRS has been performed in the murine system, although recent work has extended some of these observations to human immunology. SIRS is produced in a precursor form by Con A-stimulated murine Lyt $1^{-2} 2^{+} \mathrm{T}$ cells. This precursor is oxidized to the active (or more active) state by macrophages. To mediate suppression, SIRS-containing supernates must be added at the initiation of cell culture; however, SIRS-containing supernates cocultured with macrophages (to produce the oxidized form of SIRS) are capable of suppressing lymphoid cells when added several days after the start of culture (60).

SIRS is capable of suppressing primary and secondary IgM and IgG responses in vitro to $\mathrm{T}$ celldependent and -independent antigens, DNA synthesis responses of lymphocytes to mitogens and alloantigens, and DNA synthesis and cell division by certain tumor-cell lines (60). SIRS-mediated suppression is inhibited by various compounds including catalase, 2-mercaptoethanol (2-ME), and peroxidase substrates. It is thought that these compounds inhibit the oxidation of the SIRS precursor by macrophages (60).

SIRS has undergone partial biochemical characterization. The molecular weight of murine SIRS was initially determined to be 45 to $55 \mathrm{kD}(60)$. Later work with a murine SIRS-producing hybridoma yielded a factor with a molecular weight of 21.5 $\mathrm{kDa}$ that decreased to a molecular weight of 10 to 12 $\mathrm{kD}$ in high-ionic strength buffers (61). Three isoforms of murine SIRS have been described, with $\mathrm{p} I$ values of 5.0, 6.0, and 7.0 (62).

Recently, a murine SIRS has been partially sequenced. Antisera produced against a peptide consisting of the initial $21 \mathrm{~N}$-terminal amino acids of SIRS can block suppressive activity mediated by 
intact SIRS (63). Two mRNAs have been isolated which produce SIRS activity in a cell-free translation system. By velocity sedimentation, one mRNA is 21 to $22 \mathrm{~S}$, while the other is $25 \mathrm{~S}$. The former produces a product of molecular weight 7 to $8 \mathrm{kD}$, while the latter produced two products: one of 13 to $14 \mathrm{kD}$ and one of 7 to $8 \mathrm{kD}$. Both products had SIRS-like activity, and this activity was blocked by inhibitors of SIRS (64). The basis for the different apparent molecular weights of SIRS is unknown.

Human SIRS had been previously described to have a molecular weight of approximately $130 \mathrm{kD}$ (65); however, a later report indicated that the molecular weight of human SIRS in high-ionic strength and low-pH buffers was $15 \mathrm{kD}(66)$. Human SIRS has a $\mathrm{pI}$ of $7.0(59)$ and is inactivated at $\mathrm{pH} 2$ but not $\mathrm{pH} 4$ (65).

The mechanism of action of SIRS is under investigation. In PFC assays, SIRS does not appear to inhibit Ig synthesis but, rather, interferes with $\mathrm{Ig}$ processing and/or secretion (66). It has been suggested that SIRS mediates this immunosuppression by causing oxidation of intracellular low molecular weight thiols and protein sulfhydryls (59). One target for this oxidation is tubulin; SIRS is capable of inhibiting assembly of microtubule protein in a $\log$ concentration-dependent manner (67).

IFN-associated immunosuppression may actually be mediated by SIRS. Murine IFN-beta activates a subset of suppressor lymphocytes (Lyt $1^{-2} 2^{+}$) that suppress plaque-forming cell (PFC) responses to sheep red blood cells (SRBC). This lymphocyte subset, when activated by IFN-beta or Con A, produces supernates which show many properties similar to SIRS (60).

A similar system has been described in humans for the PFC response mediated by PWM-stimulated PBMC. This response can be suppressed by $\mathrm{CD8}^{+}$ lymphocytes activated by Con A, IFN-alpha A, or IFN-gamma. Suppression mediated by these cells or by their supernates can be blocked by inhibitors of SIRS activity, including levamisole, catalase, 2-ME, and ascorbic acid. This suppressive activity showed kinetics similar to those described for murine SIRS (65). Kaufman et al. (68) also reported that supernates from Con A-treated human lymphocytes are capable of suppressing allogeneic and syngeneic MLR without causing cytotoxicity. This suppression was described as being "SIRS-like," although the suppressive activity was not further characterized.
SIRS may also play a role in disease states. It has been reported that SIRS levels are elevated in schistosomiasis and in the nephrotic syndrome (59). Whether this elevation is a cause or a symptom of these states is unknown.

Warrington (69) described a factor similar to SIRS produced by con A-activated human T cells, called $\mathrm{T}$ cell-suppressor factor (T-SF). T-SF induces macrophages to produce macrophagederived suppressor factor (macrophage-SF) in the absence of any de novo protein synthesis. Both of these factors can suppress polyclonal B cellactivated Ig production without affecting B- or T-cell proliferation and can mediate this suppression in the absence of T-cells. T-SF activity is inhibited by 2-ME and L-rhamnose. While the activity of macrophage-SF is inhibited by L-rhamnose, only its production appears to be inhibited by 2-ME. T-SF must be added at the start of culture to mediate suppression, while macrophage-SF can be added later. T-SF has a molecular weight of approximately $20 \mathrm{kD}$, while macrophage-SF appears to be a complex with molecular weight $>110 \mathrm{kD}$ that dissociates into a $20-\mathrm{kD}$ form in high-ionic strength buffers (69).

Many properties of T-SF and macrophage-SF suggest that these molecules are identical to SIRS. However, there are some major differences in their actions. SIRS suppresses cell replication, while T-SF and macrophage-SF do not. T-SF cannot be activated to form macrophage-SF by peroxide, while SIRS can be so activated (69). Whether these two factors are identical to SIRS has yet to be determined.

Cytokine synthesis inhibitory factor (CSIF), a recently reported lymphokine now designated as IL-10, is also produced by Con A-stimulated T cells (70). Murine IL-10 is produced by one class of long-term mouse $\mathrm{T}$-cell clones, $\mathrm{T}_{\mathrm{H}} 2$ clones, and inhibits many of the functions of another class of clones, $T_{H} 1$. This includes inhibition of the production of IFN-gamma and partial inhibition of the production of other cytokines (70). IL-10 has no suppressive effects on cytokine production by $\mathrm{T}_{\mathrm{H}} 2$ clones and does not affect viability or proliferation of $T_{H} 1$ clones (71). Inhibition of IFN-gamma production is due to inhibition of mRNA synthesis and is not due to alterations in IFN-gamma secretion (71). Inhibition of other cytokines produced by $T_{H} 1$ clones, including IL-2, lymphotoxin/tumor necrosis factor (LT/TNF), IL-3, and granulocyte/macrophage colony-stimulating factor (GM-CSF), is spo- 
radic; their synthesis is inhibited only in some instances (71).

IL-10 is not capable of suppressing early cytokine synthesis. Thus it is not effective during the first 8.5 $h r$ following stimulation of clones of $T_{H} 1$ cells; only synthesis after this period is suppressed. Further, IL-10-mediated suppression is seen only in the presence of antigen-presenting cells (APC). One hypothesis is that IL-10 is modified in order to mediate suppression or IL-10 induces the synthesis of a second lymphokine which mediates suppression (71). This could be similar to the mechanism of action of SIRS, described above, where the initial "prolymphokine" is modified by macrophages to form a more active moiety.

IL-10 may also be produced in smaller amounts by unstimulated $\mathrm{T}_{\mathrm{H}} 2$ clones, but reports discussing this are contradictory (70). DNA coding IL-10 has recently been sequenced and shown to have homology with the Epstein-Barr virus gene BCRFI (70).

Other suppressive activities yet to be fully characterized, but which may be similar or identical to factors described above, include a pair of suppressor factors, SFR and SFNR, produced by allosensitized cells (72); a factor produced by PWMstimulated suppressor $\mathrm{T}$ cells capable of suppressing autologous and allogeneic IgG, IgA, and IgM synthesis (73); and a factor produced by PWM and IgG immune complex stimulated T lymphocytes bearing receptors for IgG ( $\mathrm{T}_{\mathrm{G}}$ cells) that suppresses PWM-induced B-cell differentiation (74).

\section{SUPPRESSIVE LYMPHOKINES PRODUCED BY UNSTIMULATED LYMPHOCYTES}

A small number of factors have been described that are produced by unstimulated lymphocytes. The term "unstimulated" is somewhat of a misnomer, as even lymphocytes in isolation are constantly being exposed to autologous HLA antigens, locally released mediators, and other endogenous molecules. Hence, unstimulated refers here to the lack of addition of any exogenous stimulatory molecules. As noted above, IL-10 may be produced in the absence of any stimulation (70). Small amounts of SIF may also be produced by unstimulated $\mathrm{T}$ cells (65). Mortari and Singhal (75) have described a factor produced constitutively by a suppressorenriched population of normal human bone marrow cells called bone marrow-derived suppressor factor (BDSF). BDSF suppresses in vitro primary anti- body responses and lectin-induced lymphocyte proliferation. BDSF has a molecular weight less than $1.5 \mathrm{kD}$ and contains a lipid moiety, but its production is indomethacin resistant. The cell type responsible for the production of BDSF is $\mathrm{HNK}-1^{+}$, but it does not bear surface markers of $\mathrm{T}$ or $\mathrm{B}$ cells or macrophages.

Lederman et al. (76) have also described a factor produced by unstimulated lymphocytes called immune response suppressor factor (IRSF). This factor is produced by a nonadherent cell population after $4 \mathrm{hr}$ of culture in vitro. IRSF does not affect cell viability, and its release is not inhibited by indomethacin. IRSF is heat stable and is partially dialyzable through $12-\mathrm{kD}$ exclusion size membrane. No further characterization of this factor has been performed, and its relation to other factors, including SSF (discussed below) is unknown.

Soluble receptors for $\mathrm{Fc}$ portions of IgG $(\mathrm{FcR})$ have been reported as being released from unstimulated human PBL. Although not commonly thought of as lymphokines, $\mathrm{FcR}$ fulfill the definition by being non- $\mathrm{Ab}$, immunoregulatory molecules produced by lymphocytes. FcR are capable of inhibiting the differentiation of PWM- or Nocardia opacastimulated peripheral B cells into Ig-secreting plasma cells without affecting cell viability or ${ }^{3} \mathrm{H}$ thymidine incorporation (77). Inhibition is dose dependent. Human FcR are thought to be analogues of murine immunoglobulin binding factors (IBF), glycoproteins which bind $\mathrm{Fc}$ portions of IgG and suppress the PFC response to SRBC (78) (79).

Work in our laboratory has focused on the suppressive lymphokine soluble suppressor factor (SSF). SSF is lymphokine produced by unstimulated PBL in serum-free medium (80). SSF induction is apparently a consequence of the autologous mixed lymphocyte reaction, as it is produced by neither $\mathrm{T}$ cells nor $\mathrm{B}$ cells alone. However, adherent cells are not required for its production. SSF is generated only in serum-free medium, as the presence of serum inhibits its production. Biological actions of SSF include suppression of polyclonal B-cell activation, proliferative responses of normal PBL in responses to mitogen or alloantigens, and natural killer (NK) and antibody-dependent cellular cytotoxicity $(\mathrm{ADCC})(81,82)$.

The mechanism of SSF-mediated suppression is uncertain but is not due to a cytotoxic effect (81). Binding of SSF to cell surfaces appears to involve a carbohydrate moiety, as SSF-mediated suppression of NK cytotoxicity can be inhibited in a dose- 
dependent manner by L-fucose (Fuc) or D-galactose (Gal) (83). This inhibition appears to be due to binding of SSF to the monosaccharide, rather than the monosaccharide blocking a site on the cell surface. For the inhibition of SSF-mediated suppression, monosaccharides must be present within $24 \mathrm{hr}$ following the addition of SSF to effector-cell cultures; after $24 \mathrm{hr}$, the addition of monosaccharides does not affect suppression.

Suppression mediated by SSF may be limited to preventing stimulation of lymphocytes rather than suppressing lymphocytes already stimulated. In the one-way MLR, SSF was capable of mediating suppression when added during the first 4 days of culture but not when added on day 5 or $6(81)$. This suggests that only early events in the MLR can be suppressed by SSF.

Investigations into the interaction of SSF with other lymphokines has begun. The immune modulator IFN-alpha is capable of partially reversing SSF-mediated suppression of NK cytotoxicity (82). However, recent experiments indicate that IFN can also stimulate production of SSF activity (84). This paradoxical activity of IFN may serve as a feedback inhibition mechanism within the AMLR, preventing overstimulation and possible subsequent autoimmune reactions. IL-2 is also capable of reversing SSF-mediated suppression. In contrast to the actions of IFN, however, IL-2 appears to be able to suppress production of SSF (80).

The biochemical characterization of SSF has been partially completed. SSF activity appears in the fraction $<20 \mathrm{kD}$ when separated by membrane ultrafiltration (82). On gel filtration, activity appears in two peaks: one between the $25-\mathrm{kD}$ and the $13.7-\mathrm{kD}$ markers and the second below the $13.7-\mathrm{kD}$ marker. The higher molecular weight peak showed a majority of the biological activity (82). SSF is heat stable at $56^{\circ} \mathrm{C}$ for $30 \mathrm{~min}$, but loss of suppressor activity occurs after incubation at $70^{\circ} \mathrm{C}$ for $30 \mathrm{~min}$ (81). SSF is sensitive to the proteolytic enzymes trypsin and chymotrypsin, suggesting that it is, at least in part, a polypeptide (80). Acidic conditions slightly decrease SSF's activity, while its activity is totally abrogated following treatment at basic $\mathrm{pH}$ (80). SSF also appears to be glycosylated, as SSF activity is specifically removed from SSF-containing supernates by lentil lectin (from Lens culinaris). SSF activity can be recovered following elution of lectin-bound material by $0.1 \mathrm{M}$ mannose (unpublished observation).
SSF has recently been isolated in our laboratory (85). Following controlled-pore glass (CPG) chromatography, SSF activity is found in a high-pH $(0.1$ $M$ Tris, $\mathrm{pH}$ 8.5) elution. The suppressive activity in this elution has a molecular weight less than $30 \mathrm{kD}$, is sensitive to proteases, and is inhibited by antiSSF monoclonal antibody (mAb), all identical to SSF activity in crude supernates.

On polyacrylamide gel electrophoresis, this CPG elution reveals one major band with a molecular weight of approximately $20 \mathrm{kD}$. Electroelution of this band produces material with SSF activity. This activity is also inhibited by anti-SSF mAb (85). Isoelectric focusing (IEF) gel electrophoresis of the polyacrylamide gel eluate reveals two bands, at $\mathrm{p} I$ values of 8.2 and 8.4. Upon electroeluting, the eluates from either band are capable of mediating SSF-like suppression, and this suppression is inhibited by anti-SSF mAb. We therefore conclude that this purified material is SSF. The two $\mathrm{p} I$ values may be due to alteration caused during the harsh purifcation process or to native SSF having two distinct isoforms.

SSF does not appear to be identical to other previously isolated soluble mediators. Antibodies to IFN-gamma, IL-1, IL-2, TGF-beta, platelet factor 4 (PF4), and connective tissue activating peptide III (CTAP-III) do not affect SSF-mediated suppression of NK cytotoxicity (85). Antibody to tumor necrosis factor (TNF) does partially inhibit SSFmediated suppression; however, even at a very high concentration $(100 \mathrm{U} / \mathrm{ml})$, TNF is incapable of mediating suppression of NK cytotoxicity (85). We therefore conclude that SSF and TNF are distinct moieties but may well share sequence homology to some degree.

The specific lymphocyte subpopulation responsible for the production of SSF has not yet been completely determined; however, preliminary studies indicate that the cell producing $\mathrm{SSF}$ is a $\mathrm{CD}^{+}$, $\mathrm{CD} 4^{-}, \mathrm{CD}^{+}, \mathrm{HNK}-1^{+}$lymphocyte (unpublished observation). Production of SSF is unaffected by preirradiation of lymphocytes with up to 2000 rads (80), suggesting that SSF may be produced by a unique radioresistant subset of lymphocytes of the suppressor phenotype.

Nair et al. (86) have described a suppressor factor produced by histamine-stimulated PBL (histamineinduced soluble suppressor factor, HISSF). Like SSF, this HISSF is capable of suppressing NK cytotoxicity, and this suppression can be partially reversed by IFN-alpha or IL-2. This factor shows at 
least partial sequence homology to SSF, as a mAb generated against HISSF is capable of neutralizing the activity of SSF (unpublished observation). Thus it remains to be determined if histamine can upregulate SSF production/activity or whether SSF and HISSF are two distinct moieties.

\section{CONCLUSION}

Our understanding of the role of lymphokines in immunosuppression has greatly increased over the past few years. It is now evident that suppressive lymphokines, or lymphokines with certain suppressive functions, are vital for the homeostasis of the immune system and are probably involved in the etiology and pathogenesis of a number of disease states. Unfortunately, there has been little characterization of most of these lymphokines beyond initial descriptions. To further our understanding of the complex interactions within immune responses, in both in normal states and diseased or altered states, a more rigorous examination of various suppressive activities is necessary. Similarities or identities between different mediators can then be determined, and a more integrated picture of immune regulation may be revealed.

\section{REFERENCES}

1. Dumonde DC, Wolstencroft RA, Panayi GS, Matthew M, Morley J, Howson WT: "Lymphokines": Non-antibody mediators of cellular immunity generated by lymphocyte activation. Nature 224:38-42, 1969

2. Gershon RK, Kondo K: Cell interactions in the induction of tolerance: The role of thymic lymphocytes. Immunology 18:723-737, 1970

3. Gershon RK, Cohen P, Hencin R, Liebhaber SA: Suppressor T cells. J Immunol 108:586-590, 1972

4. Benacerraf B: Suppressor $T$ cells and suppressor factor. Hosp Pract 13:65-75, 1978

5. Kapp JA, Pierce CW, Sorensen CM: Antigen-specific suppressor T-cell factors. Hosp Pract 19:85-98, 1984

6. Benacerraf B, Greene MI, Sy MS, Dorf ME: Suppressor T cell circuits. Ann NY Acad Sci 392:300-308, 1982

7. Paraskevas F: Pathways of T cell suppression. CRC Crit Rev Immunol 5:95-148, 1984

8. Takemori T, Tada T: Properties of antigen-specific suppressive T-cell factor in the regulation of antibody response of the mouse. I. In vivo activity and immunochemical characterizations. J Exp Med 142:1241-1252, 1975

9. Taniguchi $M$, Saito $T$, Tada $T$ : Antigen-specific suppressive factor produced by a transplantable I-J bearing T-cell hybridoma. Nature 278; 555-558, 1979

10. Steinmetz $\mathbf{M}$, Minard $\mathrm{K}$, Horvath $\mathrm{S}$, McNicholas $\mathrm{J}$, Srelinger J, Wake C, Long E, Mach B, Hood L; A molecular map of the immune response region from the major histocompatibility complex of the mouse. Nature $300: 35-42,1982$

11. Uytdehaag $F$, Heijnen $\mathrm{CJ}$, Pot $\mathrm{KH}$, Ballieux RE: T-T interactions in the induction of antigen-specific human suppressor T lymphocytes in vitro. J Immunol 123:646-653, 1979

12. Uytdehaag F, Heijnen CJ, Pot KH, Ballieux RE: Antigenspecific human $\mathrm{T}$ cell factors. II. T cell suppressor factor: Biological properties. J Immunol 126:503-507, 1981

13. Bendtzen $\mathrm{K}$, Bendixen $\mathrm{G}$ : Inflammatory, non-antibody lymphocytic mediators (lymphokines). Allerg Immunol (Lepiz) 26:293-303, 1980

14. Keller RH, Calvanico NJ: Suppressor macromolecules. CRC Crit Rev Immunol 5:149-199, 1984

15. Kucharz EJ, Goodwin JS: Serum inhibitors of interleukin-2. Life Sci 42:1485-1491, 1988

16. Reed JC, Nowell PC: Soluble inhibitors of T lymphocyte proliferation: Tools for dissecting pathways of $\mathrm{T}$ cell activation. Immunol Res 7:93-112, 1988

17. Blomgren H, Strander H, Cantell K: Effect of human leukocyte interferon on the response of lymphocytes to mitogenic stimuli in vitro. Scand J Immunol 3:697-705, 1974

18. Heron I, Berg K: Human leukocyte interferon: Analysis of effect on MLC and effector cell generation. Scand J Immunol 9:517-526, 1979

19. Heron I, Berg K, Cantell K: Regulatory effect of interferon on T cells in vitro. J Immunol 117:1370-1373, 1976

20. Toledano $M$, Mathiot $C$, Michon $J$, Andreu $G$, Lando D, Brandely M, Fridman WH: Interferon-gamma (IFN-gamma) and interleukin-2 in the generation of lymphokine-activated killer cell cytotoxicity-IFN-gamma-induced suppressive activity. Cancer Immunol Immunother 30:57-64, 1989

21. Johnson HM, Blalock JE: Interferon immunosuppression: Mediation by a suppressor factor. Infect Immunol 29:301305,1980

22. Rook AH, Kehrl JH, Wakefield LM, Roberts AB, Sporn MB, Burlington DB, Lane HC, Fauci AS: Effects of transforming growth factor beta on the functions of natural killer cells: Depressed cytolytic activity and blunting of interferon responsiveness. J Immunol 136:3916-3920, 1986

23. Larrick JW: Native interleukin 1 inhibitors. Immunol Today 10:61-66, 1989

24. Grimm EA, Crump WL 3rd, Durett A, Hester JP, LagooDeenadalayan S, Owen-Schaub LB: TGF-beta inhibits the in vitro induction of lymphokine-activated killing activity. Cancer Immunol Immunother 27:53-58, 1988

25. Hirano T, Kishimoto T: Interleukin-6: Possible implications in human disease. Res Clin Lab 19:1-10, 1989

26. Lipsky PE: The control of antibody production by immunomodulatory molecules. Arth Rheum 32:1345-1355, 1989

27. Teillaud JL, Brunati S, Amigorena S, Mathiot C, Sautes C, Fridman WH: Control of B cell function by Fe(gamma) receptor-positive $\mathrm{T}$ cells and immunoglobulin-binding factors. Contrib Microbiol Immunol 11:124-150, 1989

28. Castor CW, Pek S: Connective tissue activation XX. stimulation of prostaglandin secretion by mediators from lymphocytes (CTAP-1) and platelets (CTAP-III). Arth Rheum 24:504-509, 1981

29. Linker-Israeli M, Casteel N: Partial purification and characterization of systemic lupus erythematosus derived factors that suppress production of interleukin-2. J Rheum 15:952958,1988 
30. Nagaoki T, Moriya N, Miyawaki T, Seki H, Kubo M, Yokoi T, Okuda N, Taniguchi N: Suppression of B cell differentiation by dialyzable humoral factors derived from pokeweed mitogen-stimulated cord T cells. J Immunol 125:1563-158, 1980

31. Miyawaki $T$, Noriya $N$, Nagaoki $T$, Kubo M, Yokoi T, Taniguchi $\mathrm{N}$ : Mode of action of humoral suppressor factors derived from pokeweed mitogen-stimulated cord $\mathrm{T}$ cells on adult $B$ cell differentiation. J Immunol 126:282-285, 1981

32. Williams RC Jr, Korsmeyer SJ: Studies of human lymphocyte interactions with emphasis on soluble suppressor activity. Clin Immunol Immunopathol 9:335-349, 1978

33. Laurence J, Gottlieb AB, Kunkel HG: Soluble suppressor factors in patients with acquired immune deficiency syndrome and its prodrome. Elaboration in vitro by $\mathrm{T}$ lymphocyte-adherent cell interactions. J Clin Invest 72:2072-2081, 1983

34. Henderson LA, Qureshi NM, Rasheed S, Garry R: Human immunodeficiency virus-induced cytotoxicity for CD8 cells from some normal donors and virus-specific induction of a suppressor factor. Clin Immunol Immunopathol 48:174-186, 1988

35. David JR, Remold HG, Liu DY, Weiser WY, David RA: Lymphokines and macrophages. Cell Immunol 82:75-81, 1983

36. Greene WC, Fleisher TA, Waldmann TA: Soluble suppressor supernatants elaborated by concanavalin A-activated human mononuclear cells. I. Characterization of a soluble suppressor of T cell proliferation. J Immunol 126:1185-1191, 1981

37. Klesius PH: Intercellular communication: Role of soluble factors in cellular immune responses. J Am Vet Med Assoc 181:1015-1021, 1982

38. Rocklin RE: Products of activated lymphocytes. Clin Immunobiol 3:195-220, 1976

39. Hamel J, Rola-Pleszczynski M: Physiochemical characterization of human fibroblast migration inhibitory factor. Cell Immunol 96:301-311, 1985

40. Bendtzen K: Substrate specificity of the human lymphokine leucocyte migration-inhibitory factor (LIF): Radioenzymic asssay and inhibition by cGMP. Scand J Immunol 10:61-67, 1979

41. Bendtzen K, Klysner R: Increased polymorphonuclear leukocyte cGMP levels induced by the human lymphokine, leukocyte migration inhibitory factor (LIF). Immunopharm 1:323-330, 1979

42. Lomnitzer R, Rabson AR, Koornhof HJ: The effects of cyclic AMP on leucocyte inhibitory factor (LIF) production and on the inhibition of leucocyte migration. Clin Exp Immunol 24:42-48, 1976

43. Kowalczyk D, Staykowa M, Litwora E, Pryjma J, Zembala M: Partial purification and physicochemical properties of human $\mathrm{T}$ cell migration inhibitory factor (TIF). J Clin Lab Immunol 15:105-110, 1984

44. Reed JC, Robb RJ, Greene WC, Nowell PC: Effect of wheat germ agglutinin on the interleukin pathway of human $T$ lymphocyte activation. J Immunol 134:314-323, 1985

45. Fleisher TA, Greene WC, Blaese RM, Waldmann TA: Soluble suppressor supernatants elaborated by concanavalin A-activated human mononuclear cells. II. Characterization of a soluble suppressor of B cell immunoglobulin production. J Immunol 126:1192-1197, 1981
46. Greene WC, Fleisher TA, Depper JM, Leonard WJ, Stanton GJ, Waldmann TA: Characterization of a soluble suppressor of human B cell function produced by a continuous human suppressor T cell line. II. Evidence for suppression through a direct action of CTC-SISS-B on human B cells. J Immunol 129:1120-112, 1982

47. Yamaguchi $Y$, Toge T, Baba N, Kuninobu H, Kegoya $Y$, Takayama $T$, Hattori $T$ : The analysis of lymphocyte surface receptors recognized by wheat germ agglutinin for negative regulation of immune responses in cancer patients. Jap J Surg 20:51-55, 1990

48. Reed JC, Jegasothy BV, Batra BK, Weidenfeld J, Smith DR, Nowell PC: The lymphokine "inhibitor of DNA synthesis" (IDS) suppresses human T lymphocyte proliferation by an interleukin-2-independent mechanism. Lymphokine Res 5:11-20, 1986

49. Jegasothy BV, Battles DR: Immuno-suppressive lymphocyte factors. III. Complete purification and partial characterization of human inhibitor of DNA synthesis. Mol Immunol 18:395-401, 1981

50. Jegasothy BV, Namba Y, Waksman BH: Regulatory substances produced by lymphocytes. VII. IDS (inhibitor of DNA synthesis) inhibits stimulated lymphocyte proliferate by activation of membrane adenylate cyclase at a restriction point in late $G_{1}$. Immunochemistry $15: 551-555,1978$

51. Pancre V, Auriault C, Joseph M, Cesbron JY, Kusnierz JP, Capron A: A suppressive lymphokine of platelet cytotoxic functions. J Immunol 137:585-591, 1986

52. Pancre V, Joseph $M$, Capron A, Delanoye A, Vorng $\mathrm{H}$, Auriault $\mathrm{C}$ : Characterization of a suppressive factor of platelet cytotoxic functions in human and rat schistosomiasis mansoni. Clin Exp Immunol 76:417-421, 1989

53. Rich RR, ElMasry MN, Fox EJ: Induction of suppressor $T$ cells by cytokines. Transplant Proc 20:1156-1157, 1988

54. Lau C, Budz-Tymkewycz S, Ramsden M, Lee P, Keystone EC: Impaired release of a T-cell specific suppressor factor in rheumatoid arthritis. Clin Exp Immunol 61:489-495, 1985

55. Wolf RL, Whitsed H, Rosen FS, Merler E: A soluble inhibitor of $\mathrm{B}$ and $\mathrm{T}$ cell proliferation and antibody synthesis produced by dividing human T cells. Cell Immunol 36:231241, 1978

56. Wolf RL, Merler E: Role of lipids in the immune response. I. Localization to a lipid-containing fraction of the active moiety of an inhibitor (SIF) of lymphocyte proliferation. $\mathbf{J}$ Immunol 123:1169-1174, 1979

57. Wolf RL, Andreoni J: Soluble inhibitory factor (SIF) in normal human serum. Cell Immunol 67:299-311, 1982

58. Wolf RL: Human placental cells that regulate lymphocyte function. Pediat Res 23:212-218, 1988

59. Aune TM: Role and function of antigen nonspecific suppressor factors. CRC Crit Rev Immunol 7:93-130, 1987

60. Aune TM, Pierce CW: Activation of a suppressor T-cell pathway by interferon. Proc Natl Acad Sci USA 79:38083812,1982

61. Aune TM, Webb DR, Pierce CW: Purification and initial characterization of the lymphokine soluble immune response suppressor. J Immunol 131:2848-2852, 1983

62. Webb DR, Mason K, Semenuk G, Aune TM, Pierce CW: Purification and analysis of isoforms of soluble immune response suppressor (SIRS). J Immunol 135:3238-3242, 1985

63. Devens BH, Semenuk G, Webb DR: Antipeptide antibody specific for the $\mathrm{N}$-terminal of soluble immune response 
suppressor neutralizes concanavalin $\mathbf{A}$ and IFN-induced suppressor cell activity in an in vitro cytotoxic T lymphocyte response. J Immunol 141:3148-3155, 1988

64. Nowowiejski-Wieder I, Aune TM, Pierce CW, Webb DR: Cell free translation of the lymphokine soluble immune response suppressor (SIRS) and characterization of its mRNA. J Immunol 132:556-558, 1984

65. Schnaper HW, Pierce $\mathrm{CW}$, Aune TM: Identification and initial characterization of concanavalin $A$ - and interferoninduced human suppressor factors: Evidence for a human equivalent of murine soluble immune response suppressor (SIRS). J Immunol 132:2429-2435, 1984

66. Aune TM, Pierce CW: Mechanism of SIRS action at the cellular and biochemical level. In Lymphokines, Vol 9, E Pick (ed). New York, Academic Press, 1984, p 257

67. Irons RD, Pfeifer RW, Aune TM, Pierce CW: Soluble immune response suppressor (SIRS) inhibits microtubule function in vivo and microtubule assembly in vitro. J. Immunol 133:2032-2036, 1984

68. Kaufman DB, Carnaud C, Stach JL, Bach JF: The suppressive effect of a supernate from concanavalin A-activated human lymphocytes: Effects of concanavalin A-activated lymphocytes and their supernates on cytotoxic and mixed lymphocyte reactions. Cell Immunol 47:153-162, 1979

69. Warrington RJ: Interaction of a lymphokine with normal human macrophages results in release of a suppressor factor for mitogen-induced immunoglobulin synthesis. Scand $\mathbf{J}$ Immunol 25:399-406, 1987

70. Moore KW, Vieira $P$, Fiorentino DF, Trounstine $M L$, Khan TA, Mosmann TR: Homology of the cytokine synthesis inhibitory factor (IL-10) to the Epstein-Barr virus gene BCRFI. Science 248:1230-1234, 1990

71. Fiorentino DF, Bond MW, Mosmann TR: Two types of mouse $T$ helper cell. IV. Th2 clones secrete a factor that inhibits cytokine production by Thl clones. J Exp Med 170:2081-2095, 1989

72. Bensussan A, Kalil JE, Alvarez-Lopez MR, Bouchard B, Fridman WH, Fellous M, Sasportes M: Human cells allosensitized in vitro release soluble suppressor factors: Presence of at least two distinct factors. Ann Inst Pasteur Immunol 136C:211-223, 1985

73. Saxon A, Stevens RH: Suppression of immunoglobulin production in normal human blood: Characterization of the cells responsible and mediation by a soluble $\mathrm{T}$ lymphocyte derived factor. Clin Immunol Immunopathol 10:427-437, 1978
74. Moretta L, Cristina M, Moretta A, Cooper MD: Human T lymphocyte subpopulations: Studies of the mechanism by which $\mathrm{T}$ cells bearing $\mathrm{Fc}$ receptors for IgG suppress T-dependent $B$ cell differentiation induced by pokeweed mitogen. J Immunol 122:984-990, 1979

75. Mortari F, Singhal SK: Production of human bone marrowderived suppressor factor. Effect on antibody synthesis and lectin-activated cell proliferation. J Immunol 141:3037-3042, 1988

76. Lederman MM, Ellner JJ, Rodman HM: Generation of a soluble immune response suppressor factor (IRSF) by un stimulated lymphocytes of healthy subjects. Clin Exp Immunol 45:191-200, 1981

77. Lethibichthuy, Samarut C, Brochier J, Fridman WH, Revillard JP: Suppression of mitogen-induced peripheral B cell differentiation by soluble $\mathrm{Fc}$ gamma receptors release from lymphocytes. Eur J Immunol 10:894-898, 1980

78. Gisler RH, Fridman WH: Suppression of in vitro antibody synthesis by immunoglobulin-binding factor. J Exp Med 142:507-517, 1975

79. Joskowicz M, Rabourdin-Combe C, Neauport-Sautes C, Fridman WH: Characterization of suppressive immunoglobulin-binding factor (IBF). III. Biochemical and immunochemical characteristics of IBF produced by activated $T$ cells. J Immunol 121:777-783, 1978

80. Schwartz SA, Nair MPN: Characterization of soluble suppressor factors produced by unstimulated normal human lymphocytes. In Mechanisms of Cytotoxicity by NK Cells, RB Herberman (ed). New York, Academic Press, 1985, pp $453-464$

81. Shou L, Schwartz SA, Good RA, Peng R, Chen CL: A human soluble suppressor factor affecting lymphocyte responses in vitro. Proc Natl Acad Sci USA 77:6096-6100, 1980

82. Nair MPN, Schwartz SA: Suppression of human natural and antibody-dependent cytotoxicity by soluble factors from unstimulated normal lymphocytes. J Immunol 129:25112518, 1982

83. Halpern MT, Schwartz SA: Interferon stimulates production of human soluble suppressor factor. Clin Res 34:999A, 1986

84. Halpern MT, Schwartz SA: Monosaccharide binding by the human lymphokine soluble suppressor factor (SSF). FASEB J 3:A1132, 1989

85. Halpern MT, Schwartz SA: In preparation

86. Nair MPN, Cilik JM, Schwartz SA: Histamine-induced suppressor factor inhibition of NK cells: Reversal with interferon and interleukin 2. J Immunol 136:2456-2462, 1986 